\title{
Legal Aspect of Money Market and Capital Market in Nepal
}

\author{
Suman Acharya, PhD
}

Email: sumanacharaya@gmail.com

$\&$

\section{Jyoti Koirala, PhD}

Email: get2jyoti@gmail.com

\begin{abstract}
Money market and capital market are basic building block of the economy. Money market is regulated by the central bank whereas capital market is regulated by securities regulator. Similarly, money market provides short term investment whereas capital market makes medium term and long term investment. Moreover, banks and financial institutions and insurance companies are the vehicle of money market whereas brokers companies and shareholders are the vehicle of capital market. There are various theories of capital market i.e. open system theory, internalization theory, FDI dependency theory, efficient market hypothesis, fifty percent principles, greater fool theory, odd lot theory, prospect theory, rational expectation theory, madman theory, short interest rate theory, Tobin theory etc. In Nepal, capital market makes transaction in equity shares, preference share, debentures, government bonds and mutual fund. And, Securities Act, 2063 BS (2007 AD) and Commodities Act, 2074 BS (2018 AD) are major legal instruments for capital market in Nepal and Banks and Financial Institutions Act, 2073 BS (2017 AD) and Nepal Rastra Bank Act, 2058 BS (2002 AD) are principle legal instruments for money market in Nepal. Automated system, institutional investment, long-term investment, hedging and investor protection funds are prerequisite of capital market development which are determined by foreign direct investment, stock market liquidity, economic growth, low interest rate, exchange rate and inflation etc.
\end{abstract}

\section{Introduction}

Financial market is the hub of people and organization to buy and sell securities, currencies, commodities, bond etc which is the living blood of the economy. The interaction between capital markets and money markets runs financial market system. Capital markets are used for long term assets whereas money market is used for short term assets. Basically money market has the 
maturity period of less than a year, whereas capital market has the maturity period of more than a year. It can be the unit of surplus, deficit and intermediaries; surplus unit is from saving, deficit units are from loan and intermediaries unit is the pipeline of both natures. As functionality, financial market is classified as money market and capital market whereas from the point of view of institutional classification, it can be construed as organized and unorganized market. It can be further classified as sectoral financial market i.e. agricultural, banking etc. Financial market is depicted in the figure below. ${ }^{1}$

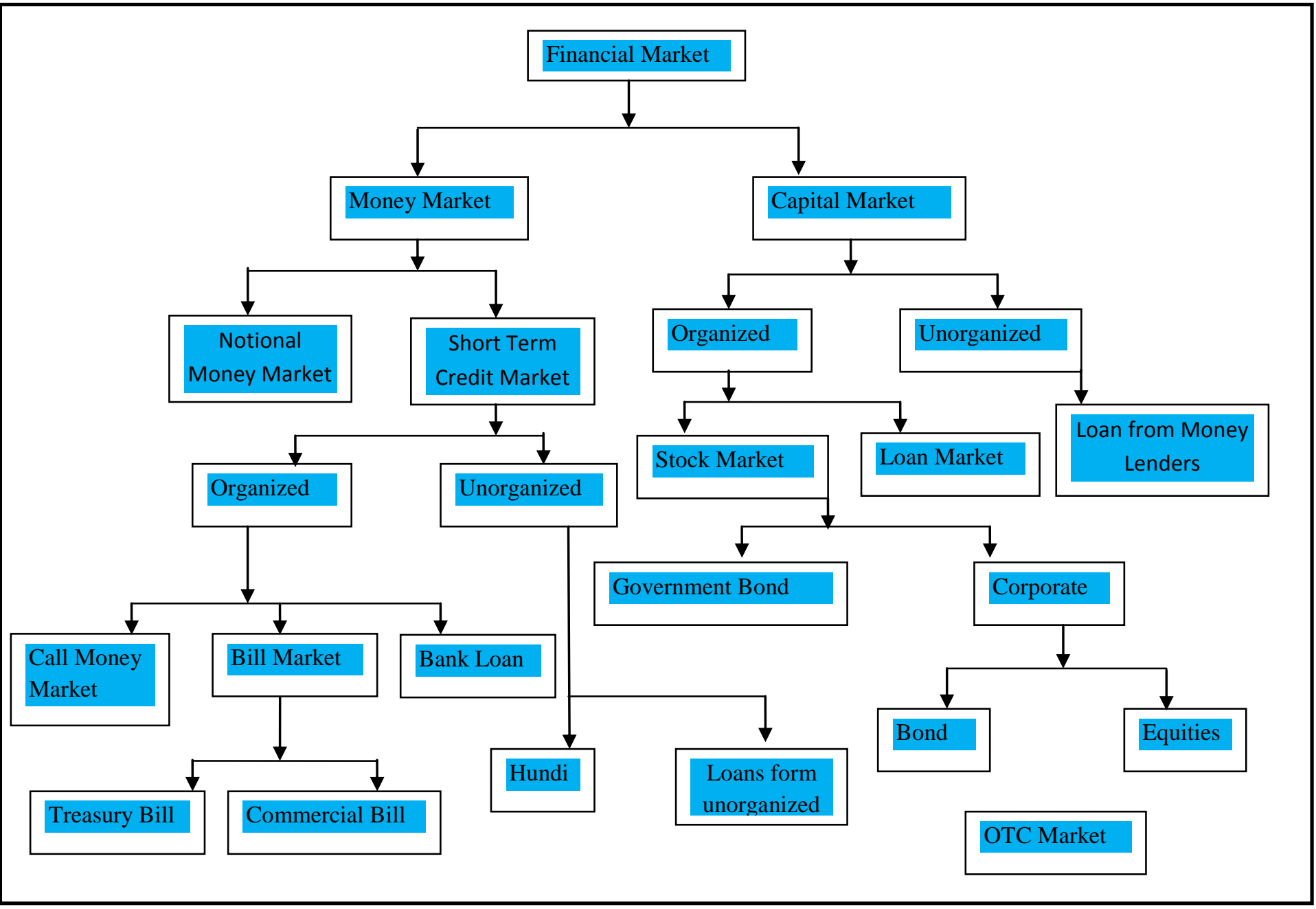

\section{Securities Market in Nepal}

Nepal Stock Exchange (NEPSE) opened its trading floor on 13 January 1994 AD (Pous 29, 2050 BS). Biratnagar Jute Mills Ltd. and Nepal Bank Ltd. floated its shares in 1994 BS (1937 AD).

1 Dr. Nilam Kumar Sharma. Monetary Economics. 89 (2070) Pairabi Publication. 
Under Company Act, 2021 BS (1964 AD), government issued bond same year. The Securities Exchange Center Ltd. was established in 2033 BS (1976 AD) for the transaction of securities in Nepal and the promotion of capital market which became NEPSE in 1993 BS (1937 AD). Securities Board of Nepal regulates capital market in Nepal under Securities Act, 2063 BS (2007 AD) which was established in 2050 BS (1993 AD) and NEPSE provides market for transactions.

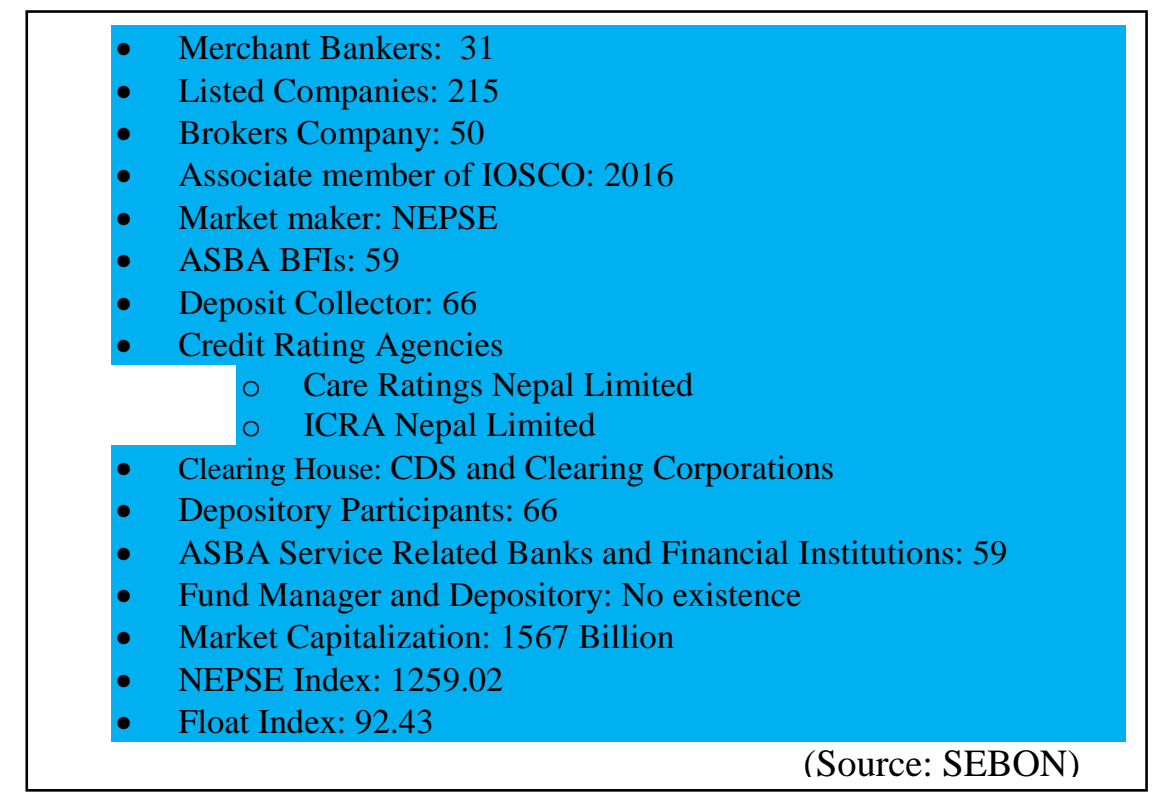

\section{Instruments of Financial Market or Securities}

In common parlance, securities refers to those instruments which can be transacted in primary and secondary markets. However, there is very wide scope of securities instruments in financial sectors. Broadly there are two kinds of securities which are marketable and nonmarketable securities. It is not surprising to use this terminology in financial instruments and similar business as investor makes investment to make their earning more secured.

\section{Laws and procedures}

\begin{tabular}{|c|c|}
\hline \begin{tabular}{ll}
\multicolumn{1}{c}{ Legislation } \\
- & Securities Act, 2063 BS (2007 AD) \\
- & Commodities Act, 2074 BS (2018 AD) \\
- & Asset (Money) Laundering Prevention Act, \\
2064 BS (2008 AD)
\end{tabular} & \begin{tabular}{ll}
\multicolumn{1}{c}{ Rules } \\
- & \multicolumn{1}{c}{ Commodity Exchange Market Rules, 2074 BS } \\
& (2018 AD) \\
- & Mutual Fund Rules, 2067 BS (2010 AD) \\
- Securities Businessperson (Merchant Banker) \\
Rules, 2064 BS (2008 AD) \\
- Specialized Investment Fund Rules, 2075 BS \\
(2018 AD) \\
- Securities listing and Trading Regulation, 2075
\end{tabular} \\
\hline
\end{tabular}




\begin{tabular}{|c|c|}
\hline & BS (2018 AD) \\
\hline $\begin{array}{l}\text { Bylaws } \\
\text { - } \quad \text { CDS Byelaws, 2068 BS (2011 AD) } \\
\text { Government Securities Bylaws of SEBON, } \\
2062 \text { BS (2005 AD) } \\
\text { Government Securities Transaction Bylaws of } \\
\text { NEPSE, 2062 BS (2005 AD) } \\
\text { - Securities Transaction Operation Bylaws, } 2075 \\
\text { BS (2018 AD) } \\
\text { - Securities Listing Bylaws, 2075 BS (2018 AD) } \\
\text { Securities Transaction Clearing and Settlement } \\
\text { Bylaws, 2069 BS (2012 AD) }\end{array}$ & $\begin{array}{l}\text { Guideline } \\
\text { - } \quad \text { Mutual Fund Guidelines, } 2069 \text { BS (2012 AD) } \\
\text { Compliance Guideline of Securities Broker, } \\
\text { 2058 BS (2002 AD) } \\
\text { - Securities Issue and Allotment Guidelines, } \\
\text { 2074 BS (2018 AD) } \\
\text { - Directives on Good Governance of Listed } \\
\text { Companies, 2074 BS (2018 AD) } \\
\text { - } \text { AML/CFT Directives, 2074 BS (2018 AD) } \\
\text { - Centralized Electronic Service Operation } \\
\text { - } \text { Directives, 2074 BS (2018 AD) } \\
\text { Securities Trading (Public Issue) Directives, } \\
\text { 2073 BS (2017 AD) }\end{array}$ \\
\hline
\end{tabular}

\section{Marketable and Non-marketable Securities}

Marketable securities refer to money market securities, capital market securities, derivatives and indirect investment whereas non-marketable securities are saving account, deposit and saving bond etc. $^{2}$ All these types of securities are not existed in Nepal.

\begin{tabular}{|c|c|}
\hline \multicolumn{2}{|c|}{ Types of Securities $^{3}$} \\
\hline $\begin{array}{cl}\text { Money market Securities } \\
\text { - } & \text { Treasury bills } \\
\text { - } & \text { Purchase agreements } \\
\text { - } & \text { Bankers acceptance } \\
\text { - } & \text { Negotiable certificates } \\
\text { - } & \text { Commercial papers }\end{array}$ & 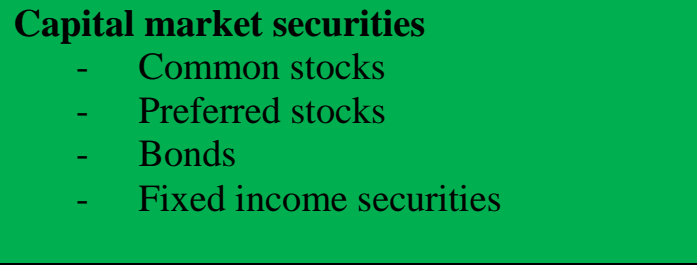 \\
\hline $\begin{aligned} & \text { Derivatives } \\
&- \text { Options } \\
&- \text { Futures } \\
&- \text { Rights } \\
&- \text { Warrants } \\
&\end{aligned}$ & $\begin{aligned} & \text { Indirect Investment } \\
&- \text { Unit trust } \\
&- \text { Investment trust }\end{aligned}$ \\
\hline $\begin{aligned} & \text { Instruments of securities market in Nepal } \\
&- \text { Common equity } \\
&- \text { Preferential share } \\
&- \text { Bond and debentures } \\
&- \text { Mutual funds }\end{aligned}$ & $\begin{array}{l}\text { Non Marketable Securities } \\
\text { - Saving Account } \\
\text { - } \text { Government Saving Bonds } \\
\text { - } \text { Mon negotiable certificate of deposit }\end{array}$ \\
\hline
\end{tabular}

In the derivative market, options provides right to the holder but not obligation to buy and sell.

Options are divided as put options and call options where put option is selling activities and a

\footnotetext{
2 Marketable Securities. http://www.buzzle.com/images/finance/securities/marketable-securities1.jpg. (Last Visited on 24 July 2016).

3 Marketable vs Non Marketable Securities: A Complete Guide. https://www.financewalk.com/marketablevs-non-marketable-securities/. (Last Visited on 4/3/2020).
} 
call option is buying activities. Futures establishes obligation to the buyers. Rights and warrants provide right of ownership and the profit from the positive performance of the company. Unit trust is the trust deeds handled by fund manager whereas investment trusts is like a mutual fund which can be both closed ended and open ended. Hedge fund is referred to non-legal private investment pools. Indirect investments are not allowed in Nepal.

Nonmarketable securities refer to those securities which cannot be sold easily in market despite the important contribution of it in investment portfolio. Saving account, government saving bonds, and non-negotiable certificate of deposit etc are nonmarketable securities. However, we pinpoint more on marketable securities as such are the target of general outlet. It does not mean nonmarketable securities are less vulnerable. There will be vigilance in deposit and withdrawal of such instruments that justifies the source of income. Non securities market refers to mutual funds, fixed deposit, saving deposits, post office saving, insurance etc. ${ }^{4}$

\section{Money Market}

Money market instruments are comparatively liquid and has relatively little period of time for maturity which may range from few days to a year. These instruments are either employed for the improvement of capital or working capital or operating expenditures, which emanates loan market, bank loan market, bill market; treasury bill market and commercial or private bills market etc. It has tremendous advantage like mobilization of saving or investment, creation of capital, source of fund raising, discouragement for capital flight, monetization of market etc.

\section{Capital Market}

Capital market is the forum of collecting capital for long term investment. This market is used for the fulfillment of capital for business expansion, acquisition, merger and similar other purpose. However, to receive capital from primary market, permission from securities regulating agencies are required. Capital market can be used both by the government and private sectors for new issues or transaction old issues of securities. There are two kinds of capital market which are primary and secondary market.

4 Non-Marketable Securities. http://www.buzzle.com/images/finance/securities/non-marketable-securities1.jpg. (Last Visited on 24 July 2016). 
- Primary Market: Primary market, also termed as new issue market, is the part of capital market through which company, government and other offers and sells stocks to the people and company to raise fund under compulsory offering to the people under existing legal provision. It supports to expand the business and operation of company or organization. Initial public offering or seasonal offering can be made.

- Secondary Market: Secondary market is the portion of capital market where stocks, bonds, debts and similar other securities are bought and sold to the investors. Investors may purchase securities or asset from this market. Their client ranges from all the walk of life of society, which makes diversity in investor portfolio.

- Over-the-Counter: Those institutions which are not listed as public companies, the stock of them are exchanged or traded in OTC. It is different than secondary market.

\section{Capital Market Instruments in Nepal}

Nepalese capital market is not sophisticated as it is in nascent phase. The following instruments are used for the transaction of capital markets in Nepal.

- Equity Shares: It is common stocks or ordinary share. Equity shareholder desires to take maximum risk of the company. They are the fractional part of company ownership.

- Preference Shares: This share is preferred stock which gets dividend prior to the equity shares. In case of the bankruptcy, preferred shareholders are entitled to get payment from the asset first.

- Debentures: It is the instrument of debt issued on the basis of creditworthiness. It has no guarantee of any collateral. Reputation is the base of this instrument.

- Government Bonds: Bond is issued in the fixed interest rate of turnover and in the maturity date the amount of face value is paid back.

- Mutual Funds: Mutual fund is the investment fund established by the group of shareholder from different background of transaction.

\section{Transfer and Transmission of Securities}

Transfer of securities refers to volunteer conveyance whereas transmission of securities implies to transfer of securities through the operation of law. The Companies Act, 2063 BS (2006 AD) provides that ownership of shares has to be transferred to the buyer within 15 days of filing application for transfer of share ownership. Nepal Stock Exchange has directed all listed 
companies, stockbrokers and share registrars to complete the process of transferring ownership of stocks within 15 days of receiving ownership transfer application. ${ }^{5}$ The shares or debentures of a company may be sold or pledged like a movable property subject to company law, securities law, memorandum of association and article of association. ${ }^{6}$ Deed documents and will paper are used to transfer share voluntarily. Public company share can be transferred only after the first annual general meeting and fully paid of the issued share. Compulsory transmission of share is done on the order of the court and voluntary transmission is registered by buyer of share. ${ }^{7}$ If the transmission process violates prevailing laws, it will not be the subject of transmission.

\section{Dematerialization of Securities}

There are various Capital Limited Companies, which are established for the service of securities related activities from where customer can get Dematerialization Form. After filling of form accompanied by photograph and the Xerox copy of citizenship certificate, Demat Account will be opened. Then, concerned company provides share checkbook. For the new issuance of share, only Demat Account number is sufficient but for a physical share certificates, it is necessary to deposit by filling the Form with correct or verified signature. With their processing time, concerned company updates share in system and sometimes owner of the share can also update in the system. Nevertheless, the approval of Capital Company is necessary for authentication.

\section{Theories of Capital Market ${ }^{8}$}

- Open System Theory: This theory argues for the environment having access for resources which promotes capital market sustainably. It is also called liberal theory of capital market.

- Internalization Theory: According to this theory, multinational corporations and their motivations in domestic market is necessary to promote capital market in the country.

\footnotetext{
5 ShareBazarNepal. Stock related news \& regulations of Nepal Stock Exchange. (Mar 17, 2020). https://www.sharebazarnepal.com.np/regulations/nepse-rules/1285-transfer-share-ownership-within-15days-nepse.html. (Last Visited on 3/31/2020).

$6 \quad$ Companies Act $\S$ Sec. 42 (2063).

7 Id. § Sec. 43.

87 Controversial Investing Theories. https://www.investopedia.com/articles/financial-theory/controversialfinancial-theories.asp. (Last Visited on 3/31/2020).
} 
Because of the internalization process, huge amount of capital may be received in the economy.

- FDI Dependency Theory: This theory argues that foreign direct investment has negative consequences to capital market.

- Efficient Market Hypothesis: Valuation of stock is based on certain standards of market and share potential which will not be changed until there are certain conditions changes. So, investor looks at the market situation for the purpose of the investment.

- Fifty Percent Principles: Stock has the behavior of ups and downs. The price change of up is corrected by half of it down and so on. If the correction of change is made fifty percent and more, there will be something wrong in the market behavior.

- Greater Fool Theory: There will be profit until others are greater fools, who are ready to pay higher price ignoring market information, reports and valuations. If they are not ready to pay more, stock will not be transacted.

- Odd Lot Theory: This theory not only focuses on buying and selling of stock but also shows the behavior of people. Individual investor sells block of odd lot of stock, which makes peculiar transactions in the market. But, they are not right or wrong.

- Prospect Theory: This theory is also called loss aversion theory. Investor wants to increase profit and hates decrease of it.

- Rational Expectations Theory: This theory tracks the certain path in which stock price walks till certain deviation path occurs. It is based on the experience of the investors.

- Madman Theory: This theory shows the status of volatility and irrationality to walk. Some investors of stock follow same, who doesn't care about market trend. They focus on their mind.

- Short Interest Theory: It shows the bullish indicators of the market in which high short interest creates short selling and buying behaviors.

- Tobin Theory: This theory argues that there is inverse relationship between interest rate and stock prices. If interest rate is high stock price which be lower and vice versa.

\section{Listing and Delisting of Companies}

Securities Board of Nepal, the regulator of securities market, issued the Securities Listing and Trading Bylaws 2075 BS (2018 AD). It divided listed companies into 'A', 'B', 'G' and ' $\mathrm{Z}$ ' 
categories. It makes transparency and accountable to shareholders to the listed companies. Better-performing companies, with a minimum paid-up capital of Rs. 20 Million, at least 1000 general shareholder and profit generating for three consecutive years, are included in Group A. Listed companies having Rs. 10-20 million, 500-1,000 shareholders, distribution of up to 10 percent dividend to shareholders for three consecutive years and submission of financial report within six months of the end of the fiscal year are included in Group 'B'. Other operating listed companies are included in Group ' $G$ ' and those companies which remained closed for two consecutive years or fail to submit financial reports on prescribed time and fail to conduct financial audit of two successive years are included in Group ' $Z$ '.

Now, the companies need to apply with the stock exchange to list their shares within 7 days of receiving offer letter while issuing shares to general public which will enable these shares to be listed as soon as they are allotted making their transaction quicker and easier. Even NEPSE is required to make system audit in every two years. There is the provision of circuit breakers in case of the upward and downward movement of market and the provision of Settlement Fund to get settled account if there is failure to settle within stipulated time.

- Listing of Companies: Trading on the floor of the NEPSE is restricted to listed corporate securities and government bonds. Corporate bodies wishing to be listed shall have to submit application in prescribed format within specified time along with certificate of incorporation, tax certificate, Memorandum of Association, Articles of Association and concerned Act, rules and regulations in the case of corporate body other than company after the incorporation and the projected Balance Sheet and Profit and Loss Account for the next three years, last three years audited financial statement, if the year of incorporation is less than three years, the Balance Sheet and Profit and Loss Account of investment in shares of subsidiary company or investment made in its parent company's share capital, details of share investment in any other company other than subsidiary, name, address, number of shares subscribed and the amount invested by shareholders having more than $5 \%$ of the share capital need to be submitted.

- Delisting of Companies: Group ' $Z$ ' Companies having failure to submit required documents in time are the subject of delisting at any time. A company failed to pay fee, failed to furnish necessary information, furnishing wrong information, failed to submit 
biannual and annual reports can be suspended from listing. ${ }^{9}$ Voluntary suspension of listing is also possible with the decision of annual general meeting with the presence of 90 percent shareholders. ${ }^{10}$

\section{Difference between Money Market and Capital Market}

As money market and capital market are the backbone of the economy, they are interrelated and are different facets of same coin.

\begin{tabular}{|l|l|l|}
\hline \multicolumn{1}{|c|}{ Issues } & \multicolumn{1}{c|}{ Money Market } & \multicolumn{1}{c|}{ Capital Market } \\
\hline Maturity period & Less than one year & More than a year \\
\hline Return volume & Low returns & High returns \\
\hline Application & $\begin{array}{l}\text { Maintaining liquidity in the } \\
\text { economy }\end{array}$ & $\begin{array}{l}\text { Mobilization in the form of long term } \\
\text { investment }\end{array}$ \\
\hline Risk factor & Low risk & High risk \\
\hline Time period & Short term & Long term \\
\hline Structures & Less organized & More Organized \\
\hline Progress & Secondary engine & Primary engine \\
\hline Instruments & $\begin{array}{l}\text { Call Money, Treasury Bill, } \\
\text { Commercial Paper, Certificate } \\
\text { of Deposit, Trade bill }\end{array}$ & $\begin{array}{l}\text { Equity/Common Stock, Debt Stock, } \\
\text { Commodity Market/Derivative } \\
\text { Market; future, Options, Spot, Forward }\end{array}$ \\
\hline Institutions & Bank, Financial Institutions & Stock Exchange \\
\hline $\begin{array}{l}\text { Role of central } \\
\text { bank }\end{array}$ & $\begin{array}{l}\text { Direct connection to central } \\
\text { bank }\end{array}$ & Indirect connection to central bank \\
\hline $\begin{array}{l}\text { Regulatory } \\
\text { agency in Nepal }\end{array}$ & Nepal Rastra Bank & Securities Exchange Board \\
\hline $\begin{array}{l}\text { Interest } \\
\text { Interest rate is determined by } \\
\text { central bank }\end{array}$ & $\begin{array}{l}\text { Interest and dividend rate are determined by } \\
\text { securities board }\end{array}$ \\
\hline
\end{tabular}

\section{Opportunities}

As money market generally deals with fixed-income securities which can be the source of income protection, capital appreciation, tax exempt saving. It has opportunities not only to market side but also to investor side. It is useful to maintain liquidity in the economy. The securities market is an important sector for raising capital, mobilizing saving for investment, facilitating organizational growth, method of redistribution of wealth, visible corporate governance, opportunity to small investors, and source of developmental project and lever of the

\footnotetext{
$9 \quad$ Securities Listing and Trading Rules $\S$ Rules 7 (2075 BS) (2018 AD). http://www.sebon.gov.np/uploads/uploads/KQpjODqlsu1YSGpg8Nrtg1kxYx7VE9ky1R7Q0V7X.pdf. (Last Visited on 4/3/2020).

$10 \quad$ Id. § Rules 8.
} 
economic activities of the country. However, Nepalese capital market is restrictive for foreign investment. No Nepali businessperson with the income of Nepal can be spent in international securities market. Capital account is not convertible in Nepal. If there is the possibility of transaction of local financial assets with foreign financial assets, it will expand the economy of the country.

\section{Challenges}

As Wall Street Journal argues that economic turmoil, regulatory reaction and technological advances are major challenges of capital market. Along with the advancement of technology, the adaptation and the possible misuse of it can be both prospects and challenges. No trading system is static which is changing and ever changing. Organizing structures are also required to be updated and revisited. Thus, demise of proprietary trading, taming derivatives, over-the-counter transaction, high powered electronic trading, hedge funds, regulatory overhang, transformational challenges like regulatory requirement, business strategy, repairmen of reputation, market structures and volatility, transitional challenges like transparency vs. margin, wealth management growth, globalization opportunities, tying the operating model to electronic trading, innovation, compensation and talent management are the challenges of contemporary capital market of the globe. ${ }^{11}$

As money markets have little challenges in comparison to capital market, the regulatory, institutional, credit maintenance, financial bubbles, natural disaster, and negative reputation are equally applicable to it. Money market instruments have also potential yield and supply challenges. Liquidity, profitability, portfolio diversity may pose a threat to money market in regular period of time. Seasonality of money market, inefficient and corrupt staff and management, inadequate banking facilities, absence of organized bill market, shortage of funds are the threat of this market. ${ }^{12}$

11 The Wall Street Journal. http://deloitte.wsj.com/cfo/2013/05/02/capital-markets-outlook-10-challenges-inan-evolving-landscape/. (Last Visited on 24 July 2016).

12 Problem of Indian Money Market. General Knowledge of Today Magazine. (2016) http://www.gktoday.in/blog/problems-of-indian-money-markets/. (Last Visited on 24 July 2016). 
Capital market fraud is willful misrepresentation of the truth with intent to deceive by one party resulting in actual or potential loss to another party or illegitimate gain to the fraudster. This includes fraudulent sale of client shares, insider trading, market manipulation, stealing of client funds, and manipulation of client records among other offence.

- False representation: Impersonation of investors and undertaking unauthorized transactions in securities accounts can be biggest issues of contemporary securities market.

- Forgery: Collection and encashment of sales proceeds by fraudsters posing as genuine investors is major incidence in the securities market across the globe.

- Unauthorized access to information: Unauthorized variation of client details in securities accounts can be biggest challenges of this market.

- Unauthorized or rogue trading. Making suspicious trades with suspicious people identified in criminal domain are also the challenges of this business.

- Market abuse and payment fraud. Abuse by trading desk and false representation of payment are also the challenges of securities market.

- Money laundering: The source of proceeds of crime received from illicit activities can be used in securities market. So, world community in the position to check this business to make clean market.

- Fictitious transaction: This market is not completely immune from transaction with unidentified identity. So, regulator and parliamentary legislations criminalizes the fictitious transaction even in securities market.

- Organized crime: The criminal groups involved from two or more countries may make securities transaction despite the stringent measures adopted by this market.

\section{- Market manipulation}

- Pump and dump: Schemes, involving use of false or misleading statements, are used to hype stocks. It involves telemarketing and internet fraud as well.

- Chop stocks: It possesses purchase in pennies and sells for dollars by providing both brokers and stock promoters massive profits with under-table payment.

- Dump and dilute: Company issue shares repeatedly for no reason other than taking investors' money away. It can be like a ponzi scheme. 
- Bait-and-switch: It may follow unauthorized trading by discouraging customers with pretentious method.

- Cheque Fraud: Submitting false cheque for illicit earning may be occurred even in securities market.

- Insider trading: Conducting trade of securities on basis of information that has not yet been released to the market or general public.

\section{Conclusion}

The growth of money market and capital market has been increasing and ever increasing across the globe. In the context of Nepal, central bank of Nepal regulates and controls money market and foreign exchange market, Insurance Board regulates insurance market whereas Securities Board of Nepal controls and regulates capital market which has only one market maker 'Nepal Stock Exchange'. There is the question of pluralism even in market maker. Nepalese finical market; money and capital market is less developed in comparison to developed and big GDP of the world.

\section{'The End...'}

